\title{
PHARMACOKINETIC STUDIES OF RANITIDINE TABLETS ON HEALTHY HUMAN SUBJECTS USING TWO BINDERS
}

N. Akhtar' ${ }^{1}$ M. Ahmad ${ }^{1}$, G. Aziz ${ }^{1}$, M. Atif ${ }^{1}$, Haji M. S. Khan ${ }^{2}$, M. Aleem $^{3}$ and A. Mahmood ${ }^{4}$

${ }^{1}$ Department of Pharmacy, Faculty of Pharmacy and Alternative Medicine, The Islamia University of Bahawalpur, PAKISTAN

${ }^{2}$ Department of Pharmacy, Hamdard University, Islamabad Campus, Islamabad, PAKISTAN

${ }^{3}$ Department of Statistics, Faculty of Science, The Islamia University of Bahawalpur, PAKISTAN

${ }^{4}$ College of Pharmacy, University of the Punjab, Lahore, PAKISTAN

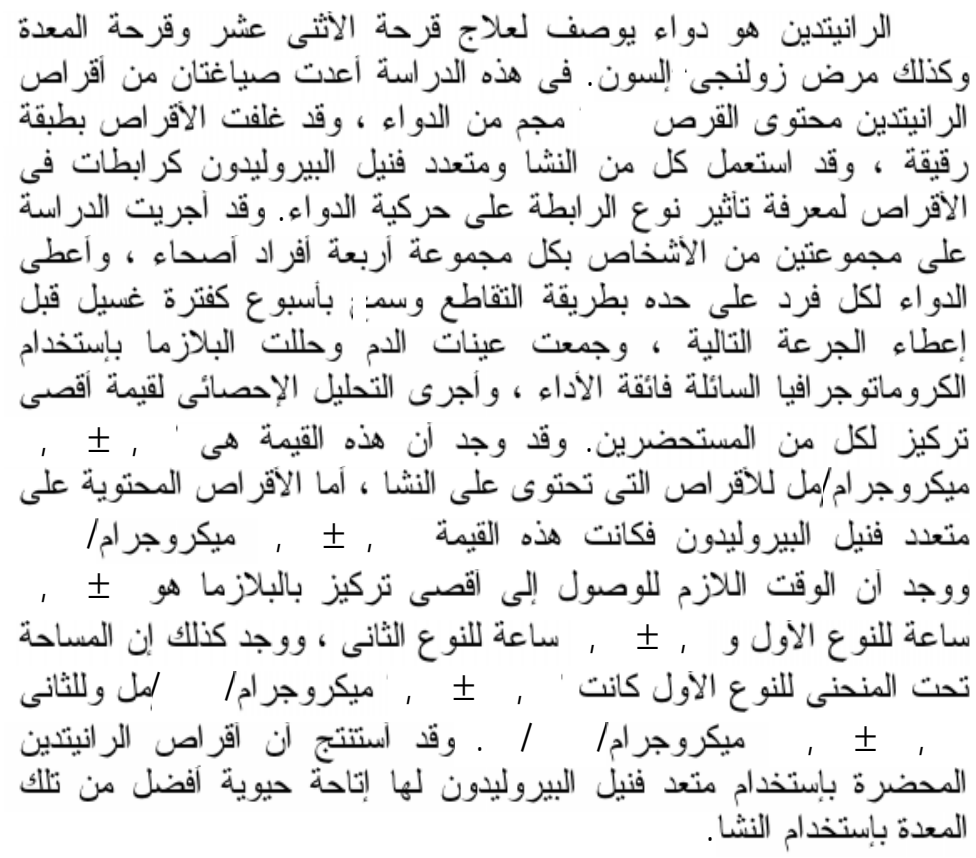

Ranitidine is an effective $\mathrm{H}_{2}$ receptor antagonist. Ranitidine is a specific, long acting $\mathrm{H}_{2}$ receptor antagonist. It is indicated for the

Received in 6/7/2006 \& Accepted in 9/12/2006 
treatment of duodenal ulcer, gastric ulcer, GERD and ZollingerEllison syndrome.

In this study two formulations of Ranitidine $300 \mathrm{mg}$ tablets were prepared and film coated. Starch and poly vinyl pyrolidone were used as binding agents to check the effect of the binding materials on the pharmacokinetic parameters of Ranitidine tablets. Different in vitro tests were used to evaluate Ranitidine tablets like disintegration test and dissolution test. Then in vivo evaluation was performed on these two formulations. Tablets were administered to eight normal human subjects comprising of two groups, each group consisted of four normal human subjects one by one in a crossover manner after one week washout period. Blood samples were collected and plasma was obtained and analyzed by HPLC. Statistical analysis was performed and the values for $C_{\max }$ for formulation 1 were found to be $4.63 \pm 0.47 \mu \mathrm{g} / \mathrm{ml}$, and for formulation 2 it was $4.76 \pm 1.02 \mu \mathrm{g} / \mathrm{ml}$. The value for $T_{\max }$ for formulation 1 was found to be $2.0 \pm 0.37$ hours, and for formulation 2 it was $1.5 \pm 0.46$ hours. The value for AUC for formulation 1 was found to be $18.57 \pm 6.122 \mu \mathrm{g} / \mathrm{hr} / \mathrm{ml}$ and for formulation 2 it was $26.43 \pm 22.38 \mu \mathrm{g} / \mathrm{hr} / \mathrm{ml}$. It was also concluded that different binders affect the bioavailability of the tablets and Ranitidine tablets prepared by polyvinyl pyrolidine have better bioavailability than those tablets prepared by starch as binding agent.

\section{INTRODUCTION}

Bioavailability is the measurement of the rate and extent (amount) of therapeutically active drug that reaches the systemic circulation and is available at site of action. Many drugs are marketed by more than one manufacturer. The study of Biopharmaceutics gives substantial evidence that the method of manufacture and the final formulation of the drug can markedly affect the bioavailability of the drug. Bioavailability studies are performed for both approved active drug ingredients and therapeutic moieties not yet approved for marketing by FDA. New formulation of the active drug ingredients or therapeutic moieties must be approved prior to marketing by the FDA. Direct and indirect methods may be used to assess drug bioavailability. The design of bioavailability study depends on the objective of the study, the ability to analyze the drug (and metabolites) in biological fluids, the pharmacodynamics of the drug substance, and the route of drug administration and the nature of the drug product. Pharmacokinetics and pharmacodynamics parameters as well as the clinical observations and 
in vitro studies may be used to determine drug bioavailability from a drug product. ${ }^{1}$

The histamine type-2 receptor antagonists $\left(\mathrm{H}_{2} \mathrm{RAs}\right)$ have made a significant impact on the prevention and management of gastro esophageal reflux and ulcers. This class includes cimetidine, famotidine, ranitidine, and nizatidine. Cimetidine, the first $\mathrm{H}_{2} \mathrm{RA}$ available, has largely been replaced by the newer agents in the class due to its adverse effect profile and the potential to cause significant drug interactions. The other $\mathrm{H}_{2} \mathrm{RAs}$ are considered equivalent. $^{2-4}$

Ranitidine is 5 times more potent than cimetidine. Though its pharmacokinetic profile is similar to cimetidine, a longer duration of action with greater than $24 \mathrm{hrs}$ acid suppression is obtained clinically. Because of higher potency some patients, not improving with the usual dose of cimetidine, have responded to Ranitidine. ${ }^{5}$

Ranitidine heals peptic ulcer by reduction in Gastric acid output. It relieves heartburn in peptic oesophagitis. In high doses it reduces gastric acid output in the zollingerEllisons syndrome. Other therapeutic uses include duodenal ulcer, benign gastric ulcer, stomal ulcer, reflux oesophagitis, zollinger-Ellison syndrome, other conditions where gastric acid reduction is beneficial e.g. prophylaxis of acid aspiration during anesthesia. ${ }^{6}$

Ranitidine is currently the second drug of choice for initial treatment and maintenance therapy in most patients with uncomplicated gastric or duodenal ulcer. Ranitidine is available in the market in $300 \mathrm{mg}$ as well as $150 \mathrm{mg}$ film coated tablets.

Excepients are added to the formulation to produce certain properties to the drug and dosage form. Some of these properties of the excepients are used to improve the compressibility of the active drug, stabilize the drug against degradation, decrease gastric irritation, control the rate of drug absorption increase drug bioavailability etc. Excepients in a drug product may also affect the dissolution kinetics of the drug. Excepients may be added intentionally to the formulation to enhance the rate and extent of drugs absorption or to delay the rate of drug absorption. Excepients, in a formulation, may interact directly with the drug to form a water soluble or water-insoluble complex. Several studies show that changing the excipients in a formulation changes the bioavailability and pharmacokinetics of the active drug. ${ }^{7}$ Binders of the tablets play an important role in the bioavailability of the active drug. In this study ranitidine tablets were prepared with two different binding agents i.e., starch and polyvinyl pyrolidine to note the effect of binding materials on the pharmacokinetic parameters of active drug.

\section{MATERIALS AND METHODS}

\section{Chemicals}

Ranitidine (Dr. Reddy's Lab India), Lactose (Riedel, Holland), 
Carboxymethyl cellulose (BDH, Germany), Microcrystalline cellulose (BDH, England), Starch (Merck, Germany), Magnesium Stearate (Merck, Germany), Talc (Merck, Germany), Cellulose Acetate Phthalate (Fluka, Switzerland), Propylene Glycol (Merck, Germany), Methylene Chloride (BDH, England), Isopropyl alcohol (Merck, Germany), Hydroxypropyl Methyl Cellulose (BDH, England), Propylene Glycol, USP (Merck, Germany), Ethyl Alcohol, 200 proof (Merck, Germany), Acetonitrile (Merck, Germany), Potassium Di-Hydrogen Phosphate (Merck, Germany), Orthophosphoric acid (Merck, Germany), Double Distilled Water

\section{Methods}

\section{Preparation of Formulations}

Two batches of ranitidine $300 \mathrm{mg}$ tablets (200 tablets each) were prepared by wet granulation method with single punch machine (Emmey Enterprises). The formulae for two Ranitidine formulations are given as:

\section{Formulation 1 (Ranitidine with Starch)}

$\begin{array}{lr}\text { Ranitidine } & 60 \mathrm{~g} \\ \text { Lactose } & 31 \mathrm{~g}\end{array}$

Microcrystalline Cellulose $31 \mathrm{~g}$

Starch $\quad 41.2 \mathrm{~g}$

Magnesium Stearate $\quad 2.8 \mathrm{~g}$

Isopropyl Alcohol (density= 0.789) $29.26 \mathrm{~g}=37.08 \mathrm{ml}$
Formulation 2 (Ranitidine with Polyvinyl pyrolidone)

Ranitidine

$60 \mathrm{~g}$

Lactose

$40 \mathrm{~g}$

Microcrystalline Cellulose $40 \mathrm{~g}$

Polyvinylpyrolidone $\quad 20.06 \mathrm{~g}$

Magnesium Stearate $\quad 2.2 \mathrm{~g}$

Isopropyl Alcohol (density $=0.789)$

$$
29.4 \mathrm{~g}=37.2 \mathrm{ml}
$$

The change in the quantities of the two ingredients i.e. magnesium stearate and lactose was due to the formulation factor and this minute change is not suppose to affect the pharmacokinetic properties of the active drug.

\section{Method of preparation}

Ranitidine, starch and microcrystalline cellulose were individually weighed and mixed, then passed through sieve \#8 and then placed in a tray. Lactose was added to this mixture and this mixture was moistened with Isopropyl Alcohol. This semisolid mass was again passed through sieve \#10 to form the granules. Granules were loaded in Fluidized bed drier (Emmay Ent., Pakistan) and dried at an inlet temperature of $60^{\circ}$ and outlet of $40^{\circ}$ for 10 minutes. Magnesium stearate was added in the granules and tablets were compressed by a single punch machine. The procedure for manufacturing of formulation 2 was same only the starch has been replaced with Polyvinylpyrolidone. Then these tablets were film coated. 


\section{Coating solution}

Hydroxypropyl Methyl

Cellulose $\quad 4 \mathrm{~g}$

Propylene Glycol, USP $1.2 \mathrm{~g}$

Ethyl Alcohol $45 \mathrm{~g}$

Methylene Chloride Q.S. 100 g

The polymer was gradually added to ethyl alcohol while the solvent was continuously agitated. A portion of methylene chloride was added to this suspension to solubilize the polymer. The propylene glycol was then added and the remainder of the methylene chloride was added. Ranitidine tablets were coated by the pan coating method (Emmay Ent., Pakistan). ${ }^{7}$ As the film coating was performed for coating of both the formulations, the thickness of the coat was so small and there was no change in the method and conditions of coating.

\section{Assay of tablets}

A validated and calibrated method for assay of active ingredient was used. ${ }^{8}$ Ten tablets were weighed and powdered in a mortar and pestle. The powder equivalent to $100 \mathrm{mg}$ of ranitidine was weighed accurately and transferred to $100 \mathrm{ml}$ volumetric flask with $70 \mathrm{ml}$ water. It was shaken for 15 minutes and was made up with water to the mark. One $\mathrm{ml}$ of this solution was transferred to $100 \mathrm{ml}$ volumetric flask and made up with water to $100 \mathrm{ml}$. The Absorbance of this solution was determined at the maximum at about $313 \mathrm{~nm}$. By taking 499 as the value of $\mathrm{A}(1 \mathrm{~cm}, 1 \%)$ the contents of Ranitidine were calculated at the maximum absorbance at about $313 \mathrm{~nm}$.

\section{In-vitro disintegration studies}

The in-vitro disintegration of both the formulations was determined using USP disintegration apparatus of six vessels (Curio, Pakistan) using water as disintegration medium. Six tablets were used for the testing of each formulation and this test was repeated for three times. The disintegration time of two formulations was compared and has been presented in Table 1

\section{In-vitro dissolution studies}

The in-vitro Ranitidine release was determined using USP 2 dissolution apparatus (Curio, Pakistan) for both the formulations using distilled water as dissolution medium and at temperature $37 \pm 2^{\circ}$ and paddle speed was set at $50 \mathrm{rpm}$.

Table 1: Assay, disintegration time of formulations 1 and 2.

\begin{tabular}{|l|c|c||}
\hline \multicolumn{1}{|c|}{ In Vitro Parameter } & Formulation 1 & Formulation 2 \\
\hline Assay of Active Drug (\%) & 93.0 & 95.0 \\
\hline Disintegration Time (Minutes) & $3.4 \pm 0.15$ & $10.7 \pm 0.2$ \\
\hline Hardness $\left(\mathrm{Kg} / \mathrm{cm}^{2}\right)$ & 6.0 & 8.6 \\
\hline
\end{tabular}


The samples were collected from each container of dissolution apparatus. The study was performed on 6 tablets. $10 \mathrm{ml}$ of each sample was diluted up to $100 \mathrm{ml}$ with dissolution medium and absorbance was taken at the $314 \mathrm{~nm}$ with UV spectrophotometer (Schimazdu, Japan).

\section{In-vivo study protocol}

In-vivo study was conducted according to the randomized two way crossover design. Eight healthy, male, non smoking adult male subjects with ages between 22 and 24 years old (mean $=22.62$ years) with heights from $154 \mathrm{~cm}$ to $169 \mathrm{~cm}$ (mean= 159.5 $\mathrm{cm}$ ), and weighing from $56 \mathrm{~kg}$ to 61 $\mathrm{kg}$ (mean $=59.5 \mathrm{~kg}$ ) participated in the study. The subjects were divided into two groups i.e., group one and group two with four subjects in each group. Written informed consent was obtained from each subject after explaining the nature and the purpose of the study. All the subjects were found healthy after performing their complete blood and urine analysis and were not receiving any medication prior two weeks and during the study period.

Each subject of group one received single oral dose of formulation 1, i.e., $300 \mathrm{mg}$ of Ranitidine tablets with starch and each subject of group two received a single oral dose of formulation 2 of Ranitidine tablets prepared with polyvinylpyrolidone as a binder. This single dose drug regimen was administered on an empty stomach; the subjects were housed at the study center from one hour before to 12 hour after the dosing. Each subject was instructed to fast over night prior to the treatment visit. The subjects were allowed to drink water at libitum. Each subject was provided with breakfast consisted of 2 scrambled eggs, 4 pieces of toast with 3 tea spoon of butter and two cups of milk. The Breakfast was provided two hours after the dosing. They were also provided the lunch after $5 \mathrm{hrs}$ of dosing time. After one week wash out period the first four subjects of group one were given the formulation 2 of Ranitidine tablets and the second four subjects of group two were given single oral dose of $300 \mathrm{mg}$ of Ranitidine tablets formulation 1 . Blood samples of $5 \mathrm{ml}$ volume were collected in preheparinized syringes at 0 (before dosing), 0.5, 1.0, 1.5, 2.0, 3.0, 4.0, 6.0, 8.0, 12.0 hours after the dosing of the Ranitidine via an indwelling cannula placed in the forearm. The plasma was harvested and frozen at $-15^{\circ}$ until assayed.

\section{Analysis of plasma}

The plasma samples were analysed using reversed phase high performance liquid chromatography (HPLC, Perkin Elmer 200 series) method. A Hypersil ODS reversed phase column $(5 \mu \mathrm{m}, 250 \mathrm{~mm} \mathrm{X}$ 4.6mm I.D.) preceeded by Spheri - 5 Silica $5-\mu \mathrm{m}$ cartridge Guard $(10 \mathrm{~mm}$ $\mathrm{x} 4.6 \mathrm{~mm}$ I.D.) column was used for the separation. The detector was operated at $314 \mathrm{~nm}$. The mobile phase consisted of potassium dihydrogen phosphate $(10 \mathrm{mM})$ and acetonitrile in the ratio of 90:10. Adjusted the $\mathrm{pH}$ 
at 3.6 with orthophosphoric acid. Filtered the mobile phase by passing through filtration assembly under vacuum using $0.45 \mu \mathrm{m}$ membrane filter (sartorius). Mobile phase was degassed by flushing it with nitrogen for 2-3 min. until complete degassing of the mobile phase was ensured.

Prior to injection, ranitidine was extracted from the plasma samples according to the following procedure: Extraction procedure was simply based on liquid-liquid extraction method. ${ }^{9}$ In the extraction procedure $900 \mu \mathrm{l}$ of the blank (thawed) plasma, $50 \mu \mathrm{l}$ of internal standard (metronidazole) solution $(20 \mu \mathrm{g} / \mathrm{ml})$ and $50 \mu \mathrm{l}$ deionized, double distilled water were mixed. After the addition of $300 \mu \mathrm{l}$ and $200 \mu \mathrm{l}$ zinc sulfate $(0.7$ $\mathrm{M})$, the mixture was vortex-mixed for 30 seconds and then centrifuged at $3000 \mathrm{rpm}$ for 5 minutes. Separated the organic layer by micropipette, filtered it by using the filtration syringe. A $20 \mu \mathrm{l}$ aliquot of supernatant was injected into HPLC system and quantification was done by comparing peak height ratio of ranitidine and internal standard.

Standard curve was constructed to encompass the anticipated range of plasma Ranitidine concentration found in healthy subjects taking ranitidine tablets. Thawed and drugfree plasma $(900 \mu \mathrm{l})$ was pipetted into a disposable test tube and spiked with $50 \mu \mathrm{l}$ of standard stock solution of ranitidine (with increasing concentration of $1.25,2.5,5$ and 10 $\mu \mathrm{g} / \mathrm{ml}$ ) and $50 \mu \mathrm{l}$ of the internal standard solution $(20 \mu \mathrm{g} / \mathrm{ml})$. Peak height ratios (ranitidine / internal standard) were measured and plotted versus plasma concentrations, in order to construct the calibration curve for plasma.

The extraction procedure was same as described earlier. ${ }^{9}$ Injections of $20 \mu \mathrm{l}$ were injected and spectra were taken of each concentration. The peak heights were noted for each concentration. The absolute recovery of ranitidine from the extraction procedure was determined at different plasma concentrations (20 to 1000 $\mathrm{ng} / \mathrm{ml}$ ) by comparing the peak heights of the drug obtained from extracted plasma samples with those obtained from direct injections of the pure Ranitidine standards in water of equivalent amounts.

\section{Data analysis}

Pharmacokinetic analysis was performed by using MS Excel Windows Professional XP. PK analysis was performed by using noncompartmental model because of no information about order of reaction and rate of absorption and it is best and convenient model to be used in such situations. Maximum concentration of Ranitidine in serum $\left(\mathrm{C}_{\max }\right)$ and times to these concentrations $\left(\mathrm{T}_{\max }\right) \quad$ were determined by visual inspection of plasma concentration time profiles. At each time points $(\mathrm{t}),\left(\mathrm{Ct} / \mathrm{C}_{\max }\right) \mathrm{X}$ $100 \%$ / individual was calculated, and the maximum and minimum values across all subjects were determined. These \% ages can provide some guidance regarding sampling times 
that can be used clinically. The area under the concentration time curve from 0 hour - $24 \mathrm{hr}$ (AUC 0- $\mathrm{t}_{24}$ ) was calculated by the linear trapezoidal rule. Statistical analysis was performed by using SPSS 10. Paired t-test was used to check the difference between the two formulations. For this purpose average concentration of the two formulations were taken and analyzed by the SPSS 10 .

\section{RESULTS AND DISCUSSION}

\section{In-vitro evaluation}

Percentages of active ingredients of both the formulations were noted and have been presented in Table 1. Both formulations of ranitidine tablets were analyzed for assay purposes by UV spectrophotomertric method. The percentage of active ingredients in the formulation 1 was found to be $93.0 \%$ and in the formulation 2 was $95.0 \%$. This is in agreement with B.P. Disintegration time for both the formulations was noted and has been presented in the Table 1. It was found that mean disintegration time for formulation 1 was found to be 3.3 minutes and mean disintegration time for formulation 2 was 10.7 minutes. The difference in the mean disintegration time of two formulations was due to difference in the binders used.

Dissolution tests were performed on both the formulations. Dissolution profiles of both the formulations have been shown in the Table 2. In the first formulation ranitidine was released in a slower pattern in comparison with the second formulation. After 45 minutes formulation 1 released up to $96.05 \%$ and the formulation 2 released up to $99.75 \%$. On the basis of this comparison it can be concluded that the formulation 2 released more Ranitidine than formulation 1. This is in accordance with U.S.P. ${ }^{10}$ Dissolution test suggests that both the formulations are bioequivalent to each other. For a specific formulation and manufacturing process, in vitro tests may be useful to assure lot -to-lot uniformity in bioavailability. However human trials may be necessary to demonstrate that bioavailability remains consistent with a given range of dissolution rate.

\section{In-vivo evaluation}

The average Ranitidine plasma concentration versus time profile for formulations 1 and 2 have been presented in Figure 1 and the average log Ranitidine plasma concentration versus time profile for both the formulations have been presented in Figure 2. Both the formulations show fluctuations at certain points. On the average formulation 2 is more bioavailable than formulation 1 .

All other pharmacokinetic parameters for formulations $1 \& 2$ of all the eight healthy subjects have been shown in Tables $3 \& 4$. Pharmacokinetic parameters along with statistical analysis for formulations 1 and 2 have been presented in Table 5.

The peak plasma drug concentration, $\mathrm{C}_{\max }$, represents the maximum plasma drug concentration obtained after oral administration of 
Table 2: Dissolution Vs time profile of formulations 1 and 2.

\begin{tabular}{|c|c|c|}
\hline Number of Tablets :6 & \multicolumn{2}{|c|}{$\begin{array}{c}\text { Dissolution Time : 45 minutes } \\
\text { (Average percentage Release) }\end{array}$} \\
\hline & Formulation 1 & Formulation 2 \\
\cline { 2 - 3 } & $96.05 \%$ & $99.75 \%$ \\
\hline
\end{tabular}

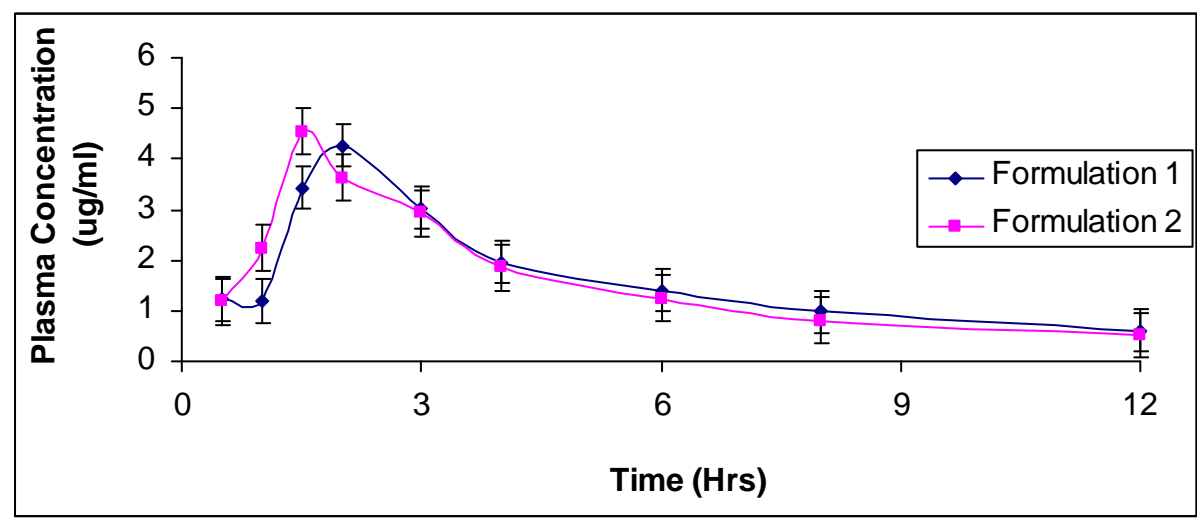

Fig. 1: Average plasma concentration \pm SEM Vs time for formulations 1 and 2 in eight subjects.

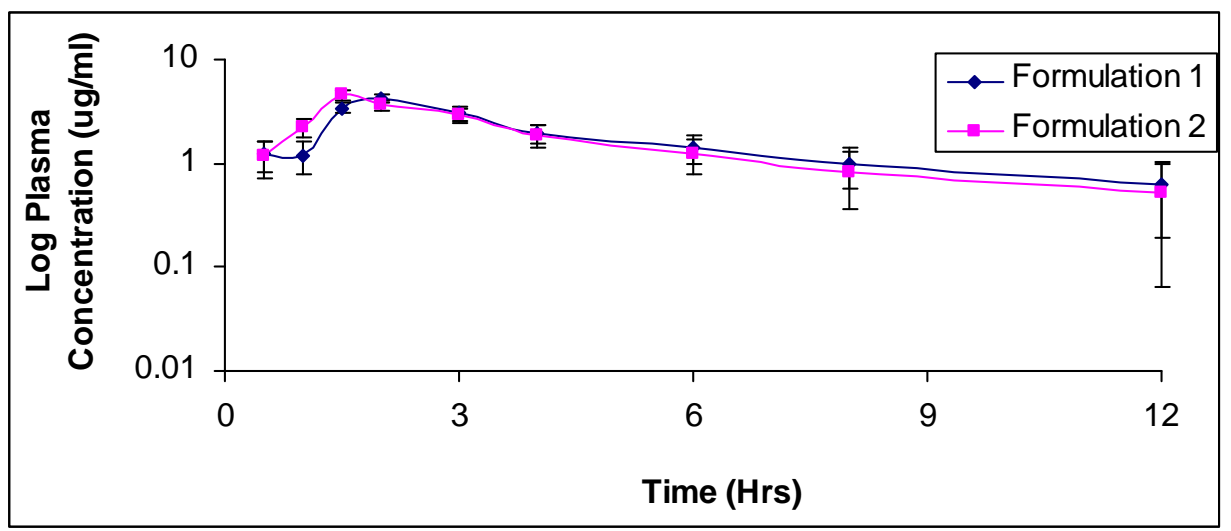

Fig. 2: Average log plasma concentration \pm SEM Vs Time for formulations 1 and 2 in eight subjects. 
Table 3: Pharmacokinetic parameters of all subjects after administering formulation 1 .

\begin{tabular}{||c|c|c|c|c|c|c|c|c||}
\hline Subject & $\begin{array}{c}\text { AUMC } \\
\left(\mu \mathrm{g} . \mathrm{h}^{2} / \mathrm{ml}\right)\end{array}$ & $\begin{array}{c}\text { AUC } \\
(\mu \mathrm{g} . \mathrm{h} / \mathrm{ml})\end{array}$ & $\begin{array}{c}\text { MRT } \\
(\mathrm{Hr})\end{array}$ & $\begin{array}{c}\mathrm{Ke} \\
(\mathrm{Hr}-1)\end{array}$ & $\begin{array}{c}\mathrm{T}_{1 / 2} \\
(\mathrm{Hr})\end{array}$ & $\begin{array}{c}\mathrm{Vd} \\
(\mathrm{L} / \mathrm{kg})\end{array}$ & $\begin{array}{c}\mathrm{VSS} \\
(\mathrm{L} / \mathrm{Kg})\end{array}$ & $\begin{array}{c}\mathrm{Cl} \\
(\mathrm{ml} / \mathrm{h} / \mathrm{kg})\end{array}$ \\
\hline 1 & 100.74 & 19.87 & 5.06 & 0.197 & 3.50 & 0.015 & 0.002 & 0.0029 \\
\hline 2 & 129.70 & 26.64 & 4.86 & 0.205 & 3.37 & 0.011 & 0.002 & 0.0022 \\
\hline 3 & 36.14 & 11.77 & 3.06 & 0.325 & 2.12 & 0.0254 & 0.008 & 0.0081 \\
\hline 4 & 68.50 & 15.87 & 4.31 & 0.231 & 2.99 & 0.0188 & 0.004 & 0.0041 \\
\hline 5 & 87.03 & 16.44 & 5.29 & 0.188 & 3.66 & 0.0182 & 0.003 & 0.0033 \\
\hline 6 & 61.72 & 15.60 & 3.95 & 0.252 & 2.74 & 0.0192 & 0.004 & 0.0047 \\
\hline 7 & 161.40 & 28.79 & 5.60 & 0.178 & 3.88 & 0.0104 & 0.001 & 0.0017 \\
\hline 8 & 42.74 & 13.65 & 3.13 & 0.319 & 2.17 & 0.0219 & 0.007 & 0.0066 \\
\hline SUM & 687.97 & 148.63 & 35.26 & 1.89 & 24.43 & 0.139 & 0.031 & 0.033 \\
\hline MEAN & 85.99 & 18.57 & 4.407 & 0.236 & 3.053 & 0.0174 & 0.0038 & 0.0042 \\
\pm & \pm & \pm & \pm & \pm & \pm & \pm & \pm & \pm \\
S.D & 43.20 & 6.122 & 0.963 & 0.057 & 0.6659 & 0.0051 & 0.0024 & 0.0022 \\
\hline
\end{tabular}

Table 4: Pharmacokinetic parameters of all subjects after administering Formulation 2.

\begin{tabular}{||c|c|c|c|c|c|c|c|c||}
\hline Subject & $\begin{array}{c}\text { AUMC } \\
\left(\mu \mathrm{g} . \mathrm{h}^{2} / \mathrm{ml}\right)\end{array}$ & $\begin{array}{c}\text { AUC } \\
(\mu \mathrm{g} . \mathrm{h} / \mathrm{ml})\end{array}$ & $\begin{array}{c}\text { MRT } \\
(\mathrm{Hr})\end{array}$ & $\begin{array}{c}\mathrm{Ke} \\
(\mathrm{Hr}-1)\end{array}$ & $\begin{array}{c}\mathrm{T}_{1 / 2} \\
(\mathrm{Hr})\end{array}$ & $\begin{array}{c}\mathrm{Vd} \\
(\mathrm{L} / \mathrm{kg})\end{array}$ & $\begin{array}{c}\mathrm{VSS} \\
(\mathrm{L} / \mathrm{Kg})\end{array}$ & $\begin{array}{c}\mathrm{Cl} \\
(\mathrm{ml} / \mathrm{h} / \mathrm{kg})\end{array}$ \\
\hline 1 & 22.96 & 79.87 & 2.87 & 0.347 & 1.99 & 0.037 & 0.013 & 0.0130 \\
\hline 2 & 117.42 & 29.29 & 4.00 & 0.249 & 2.77 & 0.010 & 0.002 & 0.0025 \\
\hline 3 & 101.75 & 24.80 & 4.10 & 0.243 & 2.84 & 0.012 & 0.002 & 0.0029 \\
\hline 4 & 65.60 & 15.29 & 4.28 & 0.233 & 2.97 & 0.019 & 0.004 & 0.0044 \\
\hline 5 & 84.51 & 14.62 & 5.77 & 0.173 & 4.00 & 0.020 & 0.003 & 0.0034 \\
\hline 6 & 35.07 & 10.59 & 3.31 & 0.302 & 2.29 & 0.028 & 0.008 & 0.0085 \\
\hline 7 & 101.15 & 18.63 & 5.42 & 0.184 & 3.76 & 0.016 & 0.002 & 0.0029 \\
\hline 8 & 70.05 & 18.40 & 3.80 & 0.262 & 2.63 & 0.016 & 0.0042 & 0.0041 \\
\hline SUM & 598.51 & 211.49 & 33.55 & 1.993 & 23.25 & 0.158 & 0.038 & 0.0417 \\
\hline MEAN & 75.72 & 26.43 & 4.193 & 0.249 & 2.906 & 0.0197 & 0.0047 & 0.0052 \\
\pm & \pm & \pm & \pm & \pm & \pm & \pm & \pm & \pm \\
S.D. & 31.60 & 22.38 & 0.980 & 0.057 & 0.681 & 0.0088 & 0.0038 & 0.0036 \\
\hline
\end{tabular}


Table 5: Statistical Analysis of Pharmacokinetic Parameters for Formulations 1 and 2 .

\begin{tabular}{|c|c|c|}
\hline Parameters & Formulation 1 & Formulation 2 \\
\hline $\mathrm{C}_{\max }(\mu \mathrm{g} / \mathrm{ml})$ & $4.63 \pm 0.47$ & $4.76 \pm 1.02 \mathrm{sig}$ \\
\hline $\mathrm{T}_{\max }(\mathrm{hours})$ & $2.0 \pm 0.37$ & $1.5 \pm 0.46 \mathrm{sig}$ \\
\hline $\mathrm{AUC}(\mu \mathrm{g} . \mathrm{h} / \mathrm{ml})$ & $18.57 \pm 6.122$ & $26.43 \pm 22.38 \mathrm{sig}$ \\
\hline $\mathrm{AUMC}\left(\mu \mathrm{g} \cdot \mathrm{h}^{2} / \mathrm{ml}\right)$ & $85.99 \pm 43.20$ & $75.72 \pm 31.60 \mathrm{sig}$ \\
\hline $\mathrm{MRT}\left(\mathrm{hours}^{-1}\right)$ & $4.40 \pm 0.963$ & $4.19 \pm 0.980 \mathrm{sig}$ \\
\hline $\mathrm{Ke}\left(\mathrm{hr}^{-1}\right)$ & $0.236 \pm 0.057$ & $0.249 \pm 0.057 \mathrm{sig}$ \\
\hline $\mathrm{T}_{1 / 2}\left(\mathrm{hours}^{1}\right)$ & $3.05 \pm 0.665$ & $2.90 \pm 0.681 \mathrm{sig}$ \\
\hline $\mathrm{VD}(\mathrm{L} / \mathrm{Kg})$ & $0.017 \pm 0.005$ & $0.019 \pm 0.0088 \mathrm{sig}$ \\
\hline $\mathrm{Vss}(\mathrm{L} / \mathrm{Kg})$ & $0.0038 \pm 0.0024$ & $0.0047 \pm 0.0038 \mathrm{sig}$ \\
\hline $\mathrm{Cl}(\mathrm{ml} / \mathrm{h} / \mathrm{Kg})$ & $0.033 \pm 0.002$ & $0.005 \pm 0.003 \mathrm{sig}$ \\
\hline
\end{tabular}

- Sig. $=$ Significant difference at $95 \%$ CI.

drug. For many drugs, a relationship is found between the pharmacodynamic drug effects and the plasma concentration. $\mathrm{C}_{\max }$ provides indications that the drug is sufficiently systemically absorbed to provide therapeutic response. In addition $\mathrm{C}_{\max }$ provides warning of possibly toxic levels of drug. ${ }^{11}$

In a pervious study conducted on adults maximum plasma concentration $\left(\mathrm{C}_{\max }\right)$ was found to be $695.3 \pm 1281.6 \mathrm{ng} / \mathrm{ml}$ for test formulation and $697.4 \pm 1298.2 \mathrm{ng} / \mathrm{ml}$ for reference formulation in 24 healthy volunteers. ${ }^{12}$ In another study on comparative bioavailability of ranitidine tablets in healthy volunteers the maximum plasma concentrations $\left(\mathrm{C}_{\max }\right)$ for test formulation was found to be $1.34 \pm 0.10 \mathrm{ng} / \mathrm{ml}$ and for the reference formulation the value was $1.21 \pm 0.10 \mathrm{ng} / \mathrm{ml} .^{13}$ In a study on comparison of two compartment model for describing ranitidine plasmatic profiles for enterohepatic recycling model the maximum plasma concentration $\left(\mathrm{C}_{\max }\right)$ ranged from 364 $\pm 57 \mathrm{ng} / \mathrm{ml}$ and for multiple sites of absorption model the value ranged from $374 \pm 54 \mathrm{ng} / \mathrm{ml} .{ }^{12}$ In a previous study on bioavailability of ranitidine in healthy Mexican volunteers : effect of food on the maximum plasma concentrations $\left(\mathrm{C}_{\max }\right)$ was found to be $921.5 \mathrm{ng} / \mathrm{ml}$ with food and 1685.2 $\mathrm{ng} / \mathrm{ml}$ with out food. ${ }^{14}$ In a study the effect of food consistency on the pharmacokinetics of ranitidine in healthy volunteers the maximum plasma concentration $\left(\mathrm{C}_{\max }\right)$ by food with solid consistency was found to be $665.81 \pm 192.21 \mathrm{ng} / \mathrm{ml}$ and with food of liquid consistency the value was $1177.30 \pm 588.19 \mathrm{ng} / \mathrm{ml} .^{15}$ In another study of plasma pharmacokinetics of ranitidine $\mathrm{HCl}$ in foals the 
maximum plasma concentrations $\left(\mathrm{C}_{\max }\right)$ was found to be $635.7 \mathrm{ng} / \mathrm{ml} .{ }^{16}$

In this study maximum plasma concentrations $\left(\mathrm{C}_{\max }\right)$ for formulation 1 was found to range from 2.39-5.75 $\mu \mathrm{g} / \mathrm{ml}$ with mean $4.63 \pm 0.47 \mu \mathrm{g} / \mathrm{ml}$ and for the formulation 2 maximum plasma concentrations $\left(\mathrm{C}_{\max }\right)$ were ranging from $2.42-7.83 \mu \mathrm{g} / \mathrm{ml}$ with the mean value $4.76 \pm 1.02 \mu \mathrm{g} / \mathrm{ml}$. These values were found to be higher than the values which have already been reported in the literature. ${ }^{11-14}$ These differences might be due to change in the population and changes in the body composition of different individual and partly due to the changes in the binder materials used in the formulation development. The mean maximum plasma concentration values for formulation 1 are less than that of formulation 2 which reflects that the formulation 2 will have better pharmacological effects than those of formulation 1. Paired t-test was performed on the average $C_{\max }$ values for two formulations. There was a significant difference between the values of $\mathrm{C}_{\max }$ for two formulations at 95\% confidence interval.

In a pervious study conducted on normal volunteers Ranitidine has $\mathrm{T}_{\max }$ $3.17 \pm 1.16$ hours for test formulation and $2.78 \pm 1.02$ hours for reference formulation. ${ }^{17}$ In another study on Comparative bioavailability of Ranitidine tablets in healthy volunteers the time of peak plasma concentrations $\mathrm{T}_{\max }$ for test formulation was found to be $3.21 \pm$ 0.24 hours and for the reference formulation the value was $3.21 \pm 0.27$ hours. ${ }^{13}$ In another study on comparison of two compartment model for describing ranitidine plasmatic profiles for enterohepatic recycling model the time of peak plasma concentration $\mathrm{T}_{\max }$ was 1.80 hours and for multiple sites of absorption model the value was 1.77 hours. ${ }^{12}$ In another study of plasma pharmacokinetics of ranitidine $\mathrm{HCl}$ in foals the time for peak plasma concentrations $T_{\max }$ was found to be 57.2 mins. $^{16}$

In this study $\mathrm{T}_{\max }$ of the formulation 1 ranged 1.5-3.0 hours with mean $2.0 \pm 0.37$ hours and $\mathrm{T}_{\max }$ of formulation 2 ranged 1.0-2.0 hours with mean $1.5 \pm 0.46$ hours. These two values were found to be less than the values reported in the pervious studies ${ }^{11-13 \& 17}$ but these values are consistent with each other. Paired ttest was performed on the average $\mathrm{T}_{\max }$ values for two formulations. There was no significant difference between the $\mathrm{T}_{\max }$ values of the two formulations at $95 \%$ confidence interval.

In a study of plasma pharmacokinetics of ranitidine $\mathrm{HCl}$ in foals the mean resident time was found to be 108.9 mins. $^{16}$

In this study Mean Residence Time (MRT) of the formulation 1 was found to be ranging from 3.06-5.6 hours with mean $4.40 \pm 0.963$ hours and MRT of the formulation 2 were ranging from 2.87-5.77 hours with mean $4.19 \pm 0.980$ hours. Paired t-test was applied on the MRT values of both the formulation and there was found a significant difference 
between the values of MRT at 95\% confidence interval.

The area under the plasma level time curve, AUC, is a measurement of the extent of drug bioavailability. The AUC is the total amount of the active drug that reaches the systemic circulation. ${ }^{11}$ In a pervious study on the pharmacokinetics of Ranitidine in 24 healthy volunteers the AUC of volunteers was $506.2 \mathrm{ng} . \mathrm{h} / \mathrm{ml}$ for test formulation and AUC for reference formulation was $486.6 \mathrm{ng} . \mathrm{h} / \mathrm{ml}{ }^{17}$ In another study on comparative bioavailability of Ranitidine tablets in healthy volunteers the Area under the curve $\mathrm{AUC}_{0-\infty}$ for test formulation was found to be $18.74 \pm 0.61 \mathrm{ng} . \mathrm{h} / \mathrm{ml}$ and for the reference formulation the value was $18.45 \pm 0.59 \mathrm{ng} . \mathrm{h} / \mathrm{ml} .{ }^{13}$ In a study on comparison of two compartment model for describing ranitidine plasma profiles for enterohepatic recycling model the Area under the curve $\mathrm{AUC}_{0-\infty}$ was 995 $\pm 462 \mathrm{ng} \cdot \mathrm{h} / \mathrm{ml}$ and for multiple sites of absorption model the value was $1789 \pm 308 \mathrm{ng} \cdot \mathrm{h} / \mathrm{ml}^{12}$ In another study of plasma pharmacokinetics of ranitidine $\mathrm{HCl}$ in foals the Area under the curve $\mathrm{AUC}_{0-\infty}$ was found to be $167.44 \mathrm{ng} . \mathrm{min} / \mathrm{ml}^{16}$

In this study $\mathrm{AUC}_{0-\infty}$ of formulation 1 ranged 11.77-28.79 $\mu \mathrm{g} . \mathrm{h} / \mathrm{ml}$ with mean $18.57 \pm 6.122$ $\mu \mathrm{g} . \mathrm{h} / \mathrm{ml}$ and $\mathrm{AUC}_{0-\infty}$ of the formulation 2 ranged 10.59-79.87 $\mu \mathrm{g} . \mathrm{h} / \mathrm{ml}$ with mean $26.43 \pm 22.38$ $\mu \mathrm{g} . \mathrm{h} / \mathrm{ml}$. Paired t-test was applied on the $\mathrm{AUC}_{0-\infty}$ of both the formulations and it was found that there is a significant difference between the
$\mathrm{AUC}_{0-\infty}$ of both the formulations at $95 \%$ confidence interval. The AUC of formulation 2 is greater than that of formulation 1 which might be due to the use of different binding materials in both the formulation as it was reflected in percentage release of active ingredient.

In a study of plasma pharmacokinetics of ranitidine $\mathrm{HCl}$ in foals the Area under the mean curve $\mathrm{AUMC}_{0-\infty}$ was found to be $18.06 \mathrm{ng}$. $\mathrm{h}^{2} / \mathrm{ml}^{16}$

In this study $\mathrm{AUMC}_{0-\infty}$ of the formulation 1 was ranging from 36.14-161.4 $\mu \mathrm{g} . \mathrm{h}^{2} / \mathrm{ml}$ with mean $85.99 \pm 43.20 \mu \mathrm{g} . \mathrm{h}^{2} / \mathrm{ml}$ and $\mathrm{AUMC}_{0-\infty}$ of the formulation 2 was ranging 22.96-117.42 $\mu \mathrm{g} . \mathrm{h}^{2} / \mathrm{ml}$ with mean $75.72 \pm 31.60 \mu \mathrm{g} . \mathrm{h}^{2} / \mathrm{ml}$. Paired t-test was applied on the $\mathrm{AUMC}_{0-\infty}$ of both the formulations and it was found that there is a significant difference between the $\mathrm{AUMC}_{0-\infty}$ of both the formulations at $95 \%$ confidence interval. The AUMC of formulation 2 is greater than that of formulation 1 which might be due to the use of different binding materials in both of the formulations as it was reflected in percentage release of active ingredient.

In a previous study the effect of food consistency on the pharmacokinetics of ranitidine in healthy volunteers, the volume of distribution by food with solid consistency was found to be $5.93 \pm$ $1.69 \mathrm{~L} / \mathrm{Kg}$ and with food of liquid consistency this value was $3.76 \pm$ $0.61 \mathrm{~L} / \mathrm{Kg} .{ }^{15}$ In another study of plasma pharmacokinetics of ranitidine 
$\mathrm{HCl}$ in foals the volume of distribution $(\mathrm{Vd})$ was found to be $1.46 \mathrm{~L} / \mathrm{Kg} .{ }^{16}$

In this study the volume of distribution $(\mathrm{Vd})$ for formulation 1 ranged $0.010-0.025 \mathrm{~L} / \mathrm{Kg}$ with mean $0.017 \pm 0.005 \mathrm{~L} / \mathrm{Kg}$ and for the formulation 2 it ranged $0.010-0.037$ $\mathrm{L} / \mathrm{Kg}$ with mean $0.019 \pm 0.0088$ $\mathrm{L} / \mathrm{Kg}$. Paired t-test was applied on the values for volume of distribution of both the formulations and it was found that there is a significant difference between the values of $\mathrm{Vd}$ of both the formulations at $95 \%$ confidence interval.

In this study volume of distribution in steady state (Vss) of the formulation 1 ranged $0.001-0.008$ $\mathrm{L} / \mathrm{Kg}$ with mean $0.0038 \pm 0.0024$ $\mathrm{L} / \mathrm{Kg}$ which is a little bit lower than the values of Vss for formulation 2 which were ranging from $0.002-0.013$ $\mathrm{L} / \mathrm{Kg}$ with mean $0.0047 \pm 0.0038$ $\mathrm{L} / \mathrm{Kg}$. These values are consistent with different values given in the literature. Paired t test was applied on the values for the volume of distribution at steady state of both the formulations and it was found that there is significant difference between the Vss of both the formulations at 95\% confidence interval.

In a pervious study on normal subjects elimination half-life was calculated with average values ranging from 2.80-3.38 hour and mean of 3.08 hour for test formulation and average values ranging from 2.87-3.40 hour and mean of 3.12 hour for reference formulation in 24 healthy individuals. ${ }^{17}$ In another study on comparative bioavailability of Ranitidine tablets in healthy volunteers the half life for test formulation was found to be $2.70 \pm$ 0.13 hour and for the reference formulation the value was $2.56 \pm 0.12$ hour. ${ }^{13}$ In a study on comparison of two compartment model for describing ranitidine plasmatic profiles for enterohepatic recycling model the half life was $2.4 \pm 0.9$ hour and for multiple sites of absorption model the value was $2.2 \pm 1.1$ hour. ${ }^{12}$ In a previous study on bioavailability of Ranitidine in healthy Mexican volunteers, effect of food on the half life was found $2.70 \pm 1.38$ hour with food and $3.66 \pm 1.34$ hour with out food. $^{14}$

In this study the plasma half life of formulation 1 ranged 2.12-3.88 hour with mean $3.05 \pm 0.665$ hour and for formulation 2 ranged 1.99-4.0 hours with mean $2.90 \pm 0.681$ hours. Paired t-test was applied on the values for plasma half life of both the formulations and it was found that there is a significant difference between the values of both the formulations at $95 \%$ confidence interval.

In a previous study on comparative bioavailability of Ranitidine tablets in healthy volunteers the elimination rate constant $\mathrm{Ke}$ for test formulation was found to be $0.27 \pm 0.01$ and for the reference formulation the value was $0.28 \pm 0.01$. $^{13}$

In this study elimination rate constant i.e. Ke of the formulation 1 
ranged $0.178-0.325$ with mean 0.236 \pm 0.057 and for the formulation 2 ranged $0.173-0.347$ with mean 0.249 \pm 0.057 . These values are consistent in both these formulations. Paired ttest was applied on the values for $\mathrm{Ke}$ of both the formulations and it was found that there is significant difference between the $\mathrm{Ke}$ of both the formulations at $95 \%$ confidence interval.

In this study Clearance $(\mathrm{Cl})$ values for formulation 1 were ranging from $0.0017-0.0081 \mathrm{ml} / \mathrm{h} / \mathrm{Kg}$ with mean $0.033 \pm 0.002 \mathrm{ml} / \mathrm{h} / \mathrm{Kg}$ and for formulation 2 these values were ranging from $0.0025-0.013 \mathrm{ml} / \mathrm{h} / \mathrm{Kg}$ with mean $0.005 \pm 0.003 \mathrm{ml} / \mathrm{h} / \mathrm{Kg}$. Paired t-test was applied on the values of $\mathrm{Cl}$ of both the formulations and it was found that there is a significant difference between the $\mathrm{Cl}$ of both the formulations at $95 \%$ confidence interval.

\section{Conclusion}

As formulation 2 released more drug than formulation 1 and values of $\mathrm{C}_{\max }$ and AUC for formulation 2 are greater than values for formulation 1 , it can be concluded that formulation of ranitidine tablets with polyvinyl pyrolidine is better than formulation of ranitidine tablets with starch.

\section{REFERENCES}

1- Leon Shargel, "Applied Biopharmaceutics \& Pharmacokinetics", $4^{\text {th }}$ Ed. Appleton \& Lange, 1999, pp. 247-252.
2- N. B. O'Mara and M. C. Nahata., J. Pharm. Tech., 10, 53 (1998).

3- B. R. Olin Ed., "Facts and Comparisons", Inc. 304-305 g (1994).

4- L. P. James and G. L. Kearns, Clin. Pharmacokinet., 31, 103 (1996).

5- K. D. Tripathi, "Essentials of Medical Pharmacology", $3^{\text {rd }}$ Ed., 1996, p. 632.

6- M. Cheema and Akhlaq-un-N Khan, "Multiauthor Pharmacology", 1998, p. 244.

7- Leon lachman and Herbert A Lieberman, "The Theory \& Practice of Industrial Pharmacy", $3^{\text {rd }}$ Ed., 1990, pp. 361-362.

8- Mass Pharma (PVT) Limited, Standard Operating Procedure QC/FG/SOP-034/01.

9- H. Jalalizadeh, M. Amini, V. Ziaee, A. Safa, H. Farsam and A. Shafiee, J. Pharma. Biomed. Analysis, 35, 665 (2004).

10- United States Pharmacopea USP/NF, Vol II, 2005, p. 1627.

11- Leon Shargel, "Applied Biopharmaceutics \& Pharmacokinetics", 4 ${ }^{\text {th }}$ Ed., Appleton \& Lange, 1999, pp. 256-259.

12- S. Paula, N. Ada and R. Modesto, Pharmacological Research, 45, 399 (2002).

13- Reza Aboofazeli and Alireza Shafaati, Iranian Journal of Pharmaceutical Research, 1 (2002).

14- H. Juarez-Olguin, J. Flores, G. Perez, G. Hernandez, C. Flores, A. Guille, A. Camacho, A. 
Toledo, M. Carrasco and I. Lares., Proc. West Pharmacol. Soc., 45, 156 (2002).

15- Hugo JuÁrez OlguÍn., Janett Flores, Gabriela Pérez and Gloria HernÁndez, Carmen., J. Pharm. Technol., 18, 178 (2002).
16- P. S. Holland, G. W. Brumbaugh, W. W. Ruoff and S. A. Brown, J. Vet. Pharmacol. Ther. Dec., 20, 447 (1997).

17- S. A. Bawazir, M. Wafik Gouda, Y. M. El-Syed, International Journal of Clinical and Therapeutics, 36, 270 (1998). 